\title{
АКТУАЛЬНІ ПИТАННЯ ВИКЛАДАННЯ ФАРМАКОГНОЗЇ̈ СТУДЕНТАМ АНГЛОМОВНОГО ВІДДІЛЕННЯ В УМОВАХ КРЕДИТНО-МОДУЛЬНОЇ СИСТЕМИ ОСВІТИ
}

\author{
Р. М. Лисюк, Р. С. Дармограй \\ Львівський національний медичний університет імені Данила Галиџького
}

\section{ACTUALITY OF PHARMACOGNOSY TEACHING FOR ENGLISH- SPEAKING STUDENTS WITHIN THE EUROPEAN CREDIT TRANSFER SYSTEM}

\author{
R. M. Lysiuk, R. Ye. Darmohray \\ Lviv National Medical University by Danylo Halytskyi
}

\begin{abstract}
У статті наведено дані щодо методичного забезпечення навчального процесу з фармакогнозії для студентів англомовного відділення ЛНМУ імені Данила Галицького. Подано детальну інформацію щодо виданого у 2011 році першого в Україні навчального посібника до лабораторних занять з фармакогнозії для студентів англомовного відділення "A Practical Course of Pharmacognosy", укладеного згідно з програмою дисципліни, що базується на принципах ЕCTS, підготовленого вітчизняними авторами.
\end{abstract}

Data on methodical provision of the educational process on Pharmacognosy for English speaking students in Danylo Halytskyi LNMU are given. The detailed information is presented concerning the first laboratory guide for English-speaking students 'A Practical Course of Pharmacognosy", complied by Ukrainian authors in accordance with the subject study programme based on principles of the ECTS.

Вступ. Забезпечення студентів сучасними підручниками та посібниками, підготовленими відповідно до оновлених навчальних програм 3 урахуванням новітніх здобутків світової та вітчизняної науки, залишається однією з основних складових покращення якості підготовки фахівців для медичної галузі [1] .

У медичних (фармацевтичних) ВНЗ України проходять підготовку на англомовному відділенні багато студентів з різних держав світу. Таким студентам необхідні підручники, підготовлені англійською мовою та укладені вітчизняними науково-педагогічними працівниками відповідно до чинних навчальних програм. В даний час надзвичайно актуальним завданням $\epsilon$ підготовка таких видань.

Організація навчального процесу при вивченні фармакогнозії повинна здійснюватися згідно з програмою навчальної дисципліни за кредитно-модульною системою [2] відповідно до нового навчального плану підготовки провізорів [3].

Основна частина. У контексті підготовки навчального процесу до умов КМСОНП працівниками кафедри фармакогнозії та ботаніки ЛНМУ імені Данила Галицького видано перший в Україні навчальний посібник до лабораторних занять з фармакогнозії для студентів англомовного відділення "A Practical Course of Pharmacognosy” (2011р.), укладений згідно з програмою дисципліни, що базується на принципах ECTS.

Матеріал практикуму представлено у повній відповідності з чинною програмою навчальної дисципліни для студентів навчальних закладів України III - IV рівнів акредитації. Дана програма розроблена зокрема і для спеціальності 8.110201 "Фармація" - освітньо-кваліфікаційного рівня "Магістр" кваліфікації "Провізор", відповідно до якого іноземні студенти здійснюють додипломну підготовку.

Представлення матеріалу практикуму відповідає вимогам, які ставляться до структури навчального посібника [4].

У передмові подано тематичний план лабораторних занять, змістових та підсумкових модулів, передбачених ECTS. У вступній частині посібника включено дефініції головних фармакогностичних термінів, зокрема щодо типів ЛРС, методів аналізу, контролю якості, стандартизації.

Наведено всі сучасні методики Європейської Фармакопеї $(Є \Phi), ~ з$ якою адаптовані видання Державної

(c) Р. М. Лисюк, Р. Є. Дармограй 
Фармакопеї України (ДФУ), які використовуються у фармакогностичному аналізі.

При представленні класу біологічно активних сполук, які вивчаються на практичних заняттях, наведено класифікацію, фізико-хімічні властивості, методи виділення з ЛРС, виявлення, хроматографічні методи аналізу, кількісне визначення, а також види біологічної активності групи БАС.

До кожного розділу підготовлено інформацію, що сприятиме кращій підготовці студентів до практичних занять: актуальність теми, конкретні навчальні цілі, перелік необхідної літератури, контрольні та програмні питання, приклади тестових завдань, об'єкти аналізу, питання для самопідготовки, завдання та методики виконання практичних завдань.

У практикумі подано інформацію про можливі домішки до фармакопейних рослин та їх порівняльні морфологічні характеристики.

Сучасні методи аналізу ефірної олії представлено відповідно до вимог методик ЕФ, з якою гармонізована ДФУ. Вони зокрема включають визначення кислотного, ефірного та гідроксильного чисел; запаху та смаку; залишку після випарювання; розчинності ефірних олій у спирті; вмісту води, сторонніх ефірів, жирних і осмолених олій у ефірних оліях; ефірної оліїу рослинних препаратах. У занятті заналізу іридоїдів подано фізико-хімічні методи ідентифікації, хроматографічне виявлення та визначення показника гіркоти.

Лабораторне заняття щодо жирних олій знайомить студентів з сучасними методами виділення та аналізу даної групи: ідентифікацією компонентів жирних олій методом тонкошарової хроматографії; визначенням числа омилення, кислотного, ефірного, пероксидного чисел; вмісту неомилюваних речовин та лужних домішок; вмісту сторонніх олій методом ТШХ; встановленням складу жирних олій методом газо-рідинної хроматографії.

Посібник до практичних занять 3 фармакогнозії дозволяє надати необхідну інформацію про основні сировинні джерела лікарських препаратів рослинного походження та методи їх аналізу, що $є$ надзвичайно важливим у практичній діяльності провізорів.

Дані щодо інших навчально-методичних видань кафедри, що використовуються у навчальному процесі студентів англомовного відділення в умовах кредитно-модульної системи, підсумовано у тезах доповіді “Досвід викладання фармакогнозії студентам англомовного відділення у ЛНМУ імені Данила Галицького" на VII Національному з'їзді фармацевтів України (Харків, 2010р.).

Висновки. Підсумовуючи вищенаведене, можна констатувати належний рівень підготовки та готовність кафедри фармакогнозії і ботаніки ЛНМУ імені Данила Галицького до проведення практичних занять $з$ фармакогнозії для студентів англомовного відділення в умовах кредитно-модульної системи організації навчального процесу.

Важливо відзначити необхідність видання за участю викладачів різних ВНЗ медичного та фармацевтичного профілю підручників та навчальних посібників для студентів англомовного відділення 3 інших дисциплін, які вивчаються на кафедрі.

МОН України № 943. від 01.10.2009p.

3. Про внесення змін до Навчального плану підготовки фахівців освітньо-кваліфікаційного рівня “Спеціаліст” кваліфікації “Провізор” у вищих навчальних закладах IV рівня акредитації за спеціальністю “Фармація”, затвердженого наказом МО3 № 930 від 07.12.2009 : наказ МО3 України № 542. від 08.07.2010 p.

4. Щодо видання навчальної літератури для вищої школи : додаток 1 до наказу МОН України № 588. від 27.06.2008. 